IZA DP No. 8586

Gary Becker's Contributions in Health Economics

Rodrigo R. Soares

October 2014 


\title{
Gary Becker's Contributions in Health Economics
}

\author{
Rodrigo R. Soares \\ Sao Paulo School of Economics - FGV \\ and IZA
}

Discussion Paper No. 8586

October 2014

\author{
IZA \\ P.O. Box 7240 \\ 53072 Bonn \\ Germany \\ Phone: +49-228-3894-0 \\ Fax: +49-228-3894-180 \\ E-mail: iza@iza.org
}

Any opinions expressed here are those of the author(s) and not those of IZA. Research published in this series may include views on policy, but the institute itself takes no institutional policy positions. The IZA research network is committed to the IZA Guiding Principles of Research Integrity.

The Institute for the Study of Labor (IZA) in Bonn is a local and virtual international research center and a place of communication between science, politics and business. IZA is an independent nonprofit organization supported by Deutsche Post Foundation. The center is associated with the University of Bonn and offers a stimulating research environment through its international network, workshops and conferences, data service, project support, research visits and doctoral program. IZA engages in (i) original and internationally competitive research in all fields of labor economics, (ii) development of policy concepts, and (iii) dissemination of research results and concepts to the interested public.

IZA Discussion Papers often represent preliminary work and are circulated to encourage discussion. Citation of such a paper should account for its provisional character. A revised version may be available directly from the author. 
IZA Discussion Paper No. 8586

October 2014

\section{ABSTRACT}

\section{Gary Becker's Contributions in Health Economics}

This short essay reviews Gary Becker's contributions and influence in health economics. It was originally prepared for the collection of short papers in honor of Gary Becker that is scheduled to appear in the inaugural issue of the Journal of Demographic Economics.

JEL Classification: I1, J1

Keywords: $\quad$ Gary Becker, health, human capital

Corresponding author:

Rodrigo R. Soares

Sao Paulo School of Economics - FGV

Rua Itapeva 474, 120 andar

01332-000 São Paulo, SP

Brazil

E-mail: rodrigo.reis.soares@fgv.br 


\section{Introduction}

Gary Becker's contribution to the field of health economics started somewhat indirectly. The early developments in human capital theory, to which Becker was one of the main contributors, had obvious implications to the economic analysis of expenditures on health, but were almost exclusively focused on schooling and training (Schultz, 1960; Becker, 1962 and 1964). Human capital theory advanced the idea that actions that imply present costs but enhanced individual productivity in the future could be seen as investments in a form of capital. Expenditures in health had many dimensions where such trade-offs were present. A good diet or exercising might not be very much fun, but potentially delivered long term benefits in the form of a longer and healthier life. Preventive medical care demanded time and money, but might also improve future health prospects. This was recognized early on, and a paper on health was even included in the 1961 conference organized by Theodore Schultz and Gary Becker that laid much of the groundwork for later developments in human capital theory (Mushkin, 1962). But the early explorations of health as human capital were somewhat timid conceptually and did not give the field a push that remotely resembled that received by the economic research on education. For the years that followed, health economics persisted mostly as a field dealing with the analysis of health systems and delivery of health technologies.

Only after a decade would the field of health economics witness the development of an encompassing theoretical framework capable of incorporating the main dimensions of health as a consumption good and human capital. Again, this contribution did not carry the authorship of Gary Becker but was impregnated with his influence. The theory that would become the working horse model in health economics for generations to come was developed by Michael Grossman in his Ph.D. dissertation at Columbia University, under the guidance of Gary Becker and Jacob Mincer (later having its main chapter published as Grossman, 1972). In Grossman's words (2004, p.631): “Gary in particular suggested the topic of my dissertation. Originally it was supposed to be a study of the effects of education on health, but along the way he encouraged (some might say demanded) me to broaden it into a theoretical and empirical analysis of the demand for health."

Grossman's (1972) theory built heavily on Becker's "A Theory of the Allocation of Time" to develop a household production model where individuals' could spend resources and time on investments to improve health (Becker, 1965). The benefits from improvements in health would materialize over time, as increased stocks of health capital delivered future utility flows (consumption value of good health), increased time available in each period of life for market and non-market production (akin to reduced morbidity, from the incapacitation perspective), and also potentially increased length of life (reduced mortality). The seeds of virtually all of the ensuing literature on health as human capital and the welfare value of health improvements, even if mostly not explicitly considered, 
were already present in Grossman's early work. These were synthetized and somewhat extended in a neat way by Becker himself, when later in life he became increasingly interested in, and worked more intensively on, topics related to health (see Becker, 2007). Some of the issues considered in this synthesis have far reaching economic implications. Three of them seem to deserve particular attention in a journal dedicated to demographic economics: determinants of optimal investments in health, the welfare value of improvements in health, and complementarities between health and other behavior. I will use this classification to help structure the discussion of the contributions of Gary Becker throughout his life to the study of health as a consumption good and human capital.

\section{Optimal Investments in Health}

The analysis of optimal investments in health involves the evolution of the stock of health over the life cycle, as considered by Grossman (1972), and its interactions with the incentives provided by available technologies and institutions. Becker's early contribution to this topic came in a paper co-authored with Isaac Ehrlich, published just a few months after Grossman's own work (Ehrlich and Becker, 1972). Ehrlich and Becker (1972) considered, in the context of a model of market insurance, the possibility of self-insurance and self-protection. The former was identified with actions that individuals could take that would reduce the loss in case of occurrence of a bad state, and the latter was taken to refer to actions that could reduce the probability of occurrence of a "bad" state. Though they explored the implications of self-insurance and self-protection in a general framework, health is an obvious candidate for this type of analysis and, in fact, was used by Ehrlich and Becker (1972) as a main example of the application of their model. Preventive health care, for example, such as exercising properly or following a good diet, may reduce the probability of a heart attack as well as the recovery prospects conditional on the occurrence of a heart attack. Ehrlich and Becker (1972) explored for the first time the implications of self-protection and self-insurance, analyzing in particular how the possibility of such behavior interacted with existing institutions, such as market insurance. They showed that market insurance and self-insurance are substitutes, but that market insurance and self-protection can be complements. More surprising, the possibility of such complementarity may lead, under certain conditions, to a reduction in the risk of hazardous events due to access to market insurance, overturning the moral hazard argument typical from the insurance literature. This possibility arises because insurance may reduce the cost of self-protection, given that it increases consumption - therefore reducing the marginal utility of consumption - in the bad state (and this partly determines the opportunity cost of expenditures on self-protection). Such considerations can be extremely important for understanding the optimal design of health insurance and even health systems, but have not been fully appreciated by the more recent literature. 
Becker revisited the interaction between market institutions and incentives to invest in health almost 30 years later, in a paper co-authored with Tomas Philipson (Philipson and Becker, 1998). Philipson and Becker (1998) analyzed how the presence of old-age mortality-contingent claims - such as annuities, survival benefits in pension plans, or any other payment conditional on individuals' length of life - affects behavior related to survival into old-age (or self-protective behavior into old-age, in the language of Ehrlich and Becker, 1972). They showed that the presence of these types of assets, which have increased dramatically across the world since the mid- $20^{\text {th }}$ century, increase investments in old-age survival above the socially optimum level, leading, in a sense, to an inefficiently high level of old-age longevity. Philipson and Becker (1998) called this effect a type of moral hazard, but notice that it is a moral hazard that works in an opposite direction to that typically discussed in the insurance literature: in the presence of annuities, individuals invest more in health and self-protection than they otherwise would. This is somewhat similar to the possibility of complementarity between market insurance and selfprotection discussed by Ehrlich and Becker (1972). In Philipson and Becker (1998), individuals do not take into account that their self-protective behavior extending survival into old-age increases the cost of the old-age insurance mechanism, leading to a socially inefficiently length of life.

\section{The Welfare Value of Health Improvements}

The results from Philipson and Becker (1998) came fundamentally from the tradeoff between quantity and quality of life that arises when one starts thinking directly about length of life as a variable that can be changed and that affects human welfare. Their main conclusion derived from the way that the introduction of annuities affected such trade-off and the incentives to invest in extended survival. The interaction between quantity and quality of life also featured prominently in Becker's contribution to the analysis of the welfare value of health improvements. Becker, Philipson, and Soares (2005) developed a parameterized version of a simplified life-cycle model in order to use the framework from the value of life literature to include health in an economically meaningful measure of aggregate welfare. Their framework considered a hypothetical individual who earned the average income per capita of a country in every year of life and that was subject to the survival probabilities observed in that country at that same point in time. Welfare comparisons across countries in a given year were then based on the evaluation of this hypothetical individual, and the income value of health gains could be expressed as the equivalent compensating variation. Based on this notion, Becker, Philipson, and Soares (2005) developed a concept of "full-income" that incorporated both gains in health and income per capita, and that could be used to assess the evolution of overall welfare and its inequality across countries. Since cross-country inequality in mortality was reduced 
substantially over the post-war period, while income inequality did not change much, this measure of "full-income" led to very different conclusions regarding the evolution of welfare inequality across countries, when compared to inequality in income per capita alone. Once survival was incorporated into the picture, one could see a monotonic reduction in welfare inequality across the world during the post-war period. Becker, Philipson, and Soares (2005) also showed that the reduction in mortality inequality across countries was mainly driven by infectious diseases and mortality at early ages. More recent advances in medical sciences - related to reductions in mortality by heart and circulatory conditions and old-age causes of death - had in fact contributed to increased health inequality across countries in the second half of the $20^{\text {th }}$ century. This paper had substantial influence on large subsequent literatures on the economic value of improvements in health, on multidimensional (economically based) welfare indices, and on the determinants and patterns of evolution of health inequalities across countries.

\section{Complementarities between Health and Other Behavior}

Though not directly focused on health itself, maybe the most influential contribution of Becker to the field of health economics was related to the complementarities between health and other behavior. His works on habits, time preferences, and investments in human capital have shed light on the important complementarities between health and addiction, health and forward looking behavior, and health and education. Becker and Murphy's (1988) theory of rational addiction explored a setting where past consumption of an addictive - or habit - good increases the current marginal utility of consumption, though possibly reducing the current level of utility. This framework explains how individuals may engage in addictive behavior even rationally and in full anticipation of the future consequences of their acts. It also sheds light on the relationship between health and addictive behavior. "Bad" addictions - those that lower future utility levels - are more costly when survival probabilities are higher. Individuals who expect to die with a high probability attach less value to the negative future consequences of addiction. On the other hand, individuals in good health have more incentives to develop good habitual behavior, which tends to increase future utility levels together with marginal utilities. Some of the implications of this theory were tested by Becker, Grossman, and Murphy (1994) for the case of cigarette addiction, but without a particular emphasis on issues related to health. This type of effect would be further reinforced if the health consequences of "bad" and "good" addictions - such as risks of overdose from drug consumption and increased probability of survival from exercising were explicitly incorporated into the model developed by Becker and Murphy (1988). In that case, as Becker (2007) alludes to, the additional effect of competing risks would further reinforce the interaction between poor health and addictive risky behavior. 
What lies behind this discussion is the idea that health, given its human capital nature, is intrinsically connected to any other behavior that implies trade-offs over time. This connection manifested itself again when Becker and Mulligan (1997) analyzed the determinants and consequences of individual investments in the subjective rate of discount over time. They considered a theory where individuals could spend resources to reduce the discount applied on future utility, or, in other words, to increase the relative value attributed to future welfare in comparison to current welfare. Becker and Mulligan (1997) conceived these investments as being related to an effort on the part of individuals to increase their own appreciation of the future, mostly through imagination and introspection, but also through consumption of market goods that would increase focus on future objectives. They extensively explored the interrelations between the possibility of investment in this "future-oriented" capital and various dimensions of health. In their theory, increases in longevity - or, equivalently, reductions in mortality rates - increase the return to investments in future-oriented capital, therefore increasing the utility weight attributed to each future period of life. Similar effects would also be triggered by the perspective of good health in the future as refers to lower morbidity, for a given pattern of survival (assuming that lower morbidity leads to an increased flow of utility in each period of life, or increased time available for production). By increasing future utility, reductions in morbidity would also raise the return to investments in future-oriented capital. It is easy to see how the extension of this theory to incorporate endogenous investments in health would immediately generate a reinforcing effect between discount rates and health. Individuals that attach more weight to the future have more incentives to invest in health in order to increase longevity and reduce future morbidity, which, in turn, increases the incentives for further investments in reducing the discount rate applied to future welfare. Rational addictions, as defined by Becker and Murphy (1988), would also display similar complementarities to investments in future-oriented capital.

The complementarity with health is probably most pervasive and economically relevant in the case of education. The early contributions of human capital theory already implied that increases in the planning horizon - or, in this case, longevity - increase the returns to investments in education (Becker, 1964). But the later development of the economics of the family and, particularly, of the economic theories of investments in children and fertility, further reinforced this link and highlighted its relevance in an intergenerational setting. Becker and Tomes (1976) explored how the incorporation of child endowments in the household problem affects the decision of parents. They showed that when deciding how much to invest in children with different endowments, parents are faced with two opposing forces: children with higher endowments generate higher return to investments in terms of human capital results, but children with lower endowments are more dependent on parental transfers to increase future welfare. 
The framework developed became by Becker and Tomes (1976) became the benchmark model to think about parental investments in children, and to understand whether parental decisions tends to compensate or to reinforce differences among children. Endowments, in their setting, were interpreted as referring to "...ability, public support, luck, and other factors" (Becker and Tomes, 1976, p.S152). In perspective, and benefiting from the last half century of advances in medical sciences, we now understand that a substantial part of these endowments is determined by health conditions before birth and during the first years of life. So it is natural to think about endowments of children and adults, and their relationship with investments in human capital, as in fact reflecting the complementarity between health and investments in education. Not only that, by thinking of endowments as related to health, the relationship between child health and fertility can also be better understood. By reducing the relative cost of child quality, improvements in health tends to shift the quantity-quality trade-off towards fewer and better educated children. The effect of child mortality can also be immediately incorporated in a setting such as this, as an extreme case in which investments in children's human capital generate have some probability of generating no return whatsoever. Indeed, this is how the more recent empirical literature has interpreted the implications of Becker and Tomes (1976). Large literatures have followed the initial theoretical explorations of Becker on investments in human capital and the impact of endowments on investments in children and fertility. Some papers have explored the two way relationship between education and health, a natural outcome of the complementarity between the two. Others have looked at the impact of indicators of health at birth and during childhood on investments in children and number of children, and also at the effect of heterogeneity in endowments within the household.

This interaction of health with human capital, embedded within a context including fertility choice, assumed yet an additional relevance when human capital theory was brought to the analysis of the determinants of the demographic transition. Becker, Murphy, and Tamura (1990) brought together several aspects of the theories of human capital, investments in children, fertility, and growth in order to develop a model that could reproduce the main economic and demographic changes observed during the last centuries. In their model, economies could display an equilibrium without investments in human capital, with high fertility, and without growth, or an equilibrium with investments in human capital, low fertility, and growth. Initial conditions and the value of some key parameters - such as productivity, cost of children, and length of life - would determine where the economy would end up. Though Becker, Murphy, and Tamura (1990) did not pay much attention to health, their framework, when coupled with the complementarities between health, human capital, and fertility discussed before, opened up the possibility of understanding the role of "exogenous" changes in health, driven by advances in medical 
and biological sciences, as driving forces behind the process of demographic transition. This approach generated a stream of research, with both theoretical and empirical contributions, exploring the role of improvements in health as determinants of the historical reductions in fertility and increases in schooling that typically follow the onset of the transition.

\section{Concluding Comments}

The last contribution of Becker to the field of health economics falls somewhat outside of the framework of health as human capital and consumption good focused here, but is still worth mentioning. Becker and Elias (2007) looked at the market for organ donations and argued, with theory and empirical evidence, that a private market for organs, including both live and cadaveric donations, could be welfare improving if properly regulated. Their logic trusted on the role of financial incentives to reduce the gap between the supply and demand of organs, a major problem for health systems around the world. Though this proposal may seem somewhat farfetched, it is gaining increasing attention in the public health debate in recent years, and has indeed been implemented in a few specific markets.

Health economics represented a relatively small and somewhat late interest in the broader research agenda of Gary Becker. Yet, it is difficult not to see his influence in virtually every topic of research in the area involving any sort of theoretical analysis or motivation. As in many other areas that he touched but briefly, Becker has left permanent imprints on the economic analysis of health as consumption good and human capital. The longevity of his ideas will continue to be strong complements to future advances in health economics for a long time to come.

\section{References}

Becker, Gary S. (1962). Investment in Human Capital: A Theoretical Analysis. Journal of Political Economy, 70(5), part 2, 9-49.

Becker, Gary S. (1964). Human Capital: A Theoretical and Empirical Analysis, with Special Reference to Education. University of Chicago Press, Chicago.

Becker, Gary S. (1965). A Theory of the Allocation of Time. Economic Journal, LXX(299), 493-508.

Becker, Gary S. (2007). Health as Human Capital: Synthesis and Extensions. Oxford Economic Papers, 59(3), 379-410.

Becker, Gary S. and Julio J. Elias (2007). Introducing Incentives in the Market for Live and Cadaveric Organ Donations. Journal of Economic Perspectives, 21(3), 3-24.

Becker, Gary S., Michael Grossman, and Kevin M. Murphy (1994). An Empirical Analysis of Cigarette Addiction. American Economic Review, 84(3), 396-418. 
Becker, Gary S. and Casey B. Mulligan (1997). The Endogenous Determination of Time Preference. Quarterly Journal of Economics, CXII(2), 729-758.

Becker, Gary S. and Kevin M. Murphy (1988). A Theory of Rational Addiction. Journal of Political Economy, 96(4), 675-700.

Becker, Gary S., Kevin M. Murphy, and Robert Tamura (1990). Human Capital, Fertility, and Economic Growth. Journal of Political Economy, 98(2), S12-S70.

Becker, Gary S., Tomas J. Philipson, and Rodrigo R. Soares (2005). The Quantity and Quality of Life and the Evolution of World Inequality. American Economic Review, 95(1), 277-291.

Becker, Gary S. and Nigel Tomes (1976). Child Endowments and the Quantity and Quality of Children. Journal of Political Economy, 84(4), part 2, S143-S62.

Ehrlich, Isaac and Gary S. Becker (1972). Market Insurance, Self-Insurance, and SelfProtection. Journal of Political Economy, 80(4), 623-48.

Grossman, Michael (1972). On the Concept of Health Capital and the Demand for Health. Journal of Political Economy, 80(2), 223-255.

Grossman, Michael (2004). The Demand for Health, 30 Years Later: A Very Personal Retrospective and Prospective Reflection. Journal of Health Economics, 23(4), 629-636.

Mushkin, Selma J. (1962). Health as an Investment. Journal of Political Economy, 70(5), Part 2: Investment in Human Beings, 129-157.

Philipson, Tomas J. and Gary S. Becker (1998). Old-Age Longevity and Mortality-Contingent Claims. Journal of Political Economy, 106(3), 551-573.

Schultz , Theodore W. (1960). Capital Formation by Education. Journal of Political Economy, 68(6), 571-583. 